Report to Congress

\title{
1996 Annual Report on Low-Level Radioactive Waste Management Progress
}

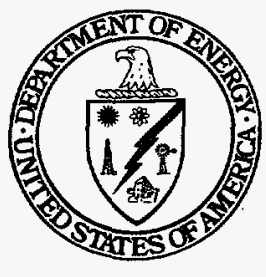

U.S. Department of Energy

Office of Environmental Management Washington, DC 20585

November 1997 


\section{The Secretary of Energy}

Washington, DC 20585

November 28, 1997

The Honorable Al Gore

President of the Senate

Washington, D.C. 20510

Dear Mr. President:

Enclosed is the "1996 Annual Report on Low-Level Radioactive Waste Management Progress," submitted in response to section 7(b) of the Low-Level Radioactive Waste Policy Act (the Act). This is the eleventh annual report submitted by the Department of Energy on the progress of States and compact regions in establishing disposal facilities for commercially-generated low-level radioactive waste.

The Act sets forth a framework to encourage States to establish new disposal facilities through a series of incentives and penalties. The Act encourages States to form interstate compacts for low-level radioactive waste disposal. After compacts have been approved by Congress, compact member States may limit access to their regional disposal facilities to low-level radioactive waste generated within the respective compact regions. Forty-one States have formed nine compact regions, all of which have received congressional approval.

Since 1996, there have been a number of developments that are not reflected in the enclosed annual report. For example, a proposed tenth compact consisting of Maine, Texas, and Vermont, having been previously introduced twice, was introduced in Congress for approval again in the 1997 session. In October, this legislation passed in the House of Representatives. In April 1996, the State of Texas issued a proposed draft operating license for a new low-level radioactive waste disposal facility and an environmental and safety analysis in support of the licensing decision. Under Texas' licensing process, administrative hearings will be held on the draft license and the supporting analysis. If the licensing decision is upheld and there is no subsequent litigation, construction of the disposal facility could begin in late 1998.

An operating license for a new disposal facility in California was issued in 1993, but construction of the facility has been delayed by issues related to the transfer of land from the Federal Government to the State of California. However, progress

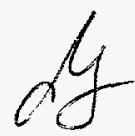

BSTRIBUTION OF THIS DOCUMENT IS UNLIMTRED 
had been made in 1997 to define water infiltration studies that will be conducted by the State of California and the Department of the Interior. Under an agreement reached in October 1997, the Department of Energy will make the services of the Lawrence Livermore National Laboratory available to both parties for analyzing soil samples with the understanding that the parties will share the raw data generated from these laboratory tests.

The 1995 reopening of the disposal facility in South Carolina for waste generated nationally (except from North Carolina), and the availability of a disposal facility in Utah for certain types of low-level radioactive waste, have apparently alleviated some storage concerns and lessened the pressure in certain States to establish new facilities. The report notes that in 1996, compact host States continued their efforts to develop new disposal sites, while the five States who are not members of a compact, as well as the District of Columbia and Puerto Rico, either have no disposal facility development plans or have exercised only limited efforts to develop their own facilities. However, in 1997, the Midwest Compact has decided to discontinue its siting effort, while Illinois has suspended its siting process until nuclear power reactors begin decommissioning in 2012.

Future events that have the potential to influence activities and decisions related to low-level radioactive waste management include: a decision on the transfer of Federal land for the California site; congressional approval of the Texas Compact; a decision on a license to develop a proposed facility in Nebraska; and results from newly intensified site investigations at the proposed North Carolina site, the largest of the proposed regional facilities.

In accordance with the Act, the Department of Energy continues to provide technical assistance to States and compact regions developing new disposal sites for low-level radioactive waste. If you have further questions, please contact me or have a member of your staff contact Mr. John C. Angell, Assistant Secretary for Congressional and Intergovernmental Affairs, at (202) 586-5506.

Sincerely,

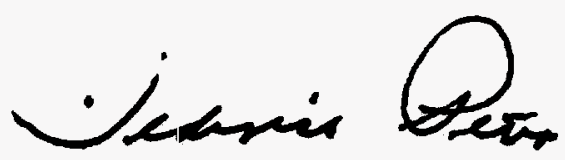

Federico Peña

Enclosure 


\section{DISCLAIMER}

Portions of this document may be illegible electronic image products. Images are produced from the best available original document. 
The Honorable Al Gore

President of the Senate

Washington, D.C. 20510

The Honorable Frank Murkowski

Chairman

Committee on Energy

and Natural Resources

United States Senate

Washington, D.C. 20510

The Honorable Dale Bumpers

Ranking Minority Member

Committee on Energy

and Natural Resources

United States Senate

Washington, D.C. 20510

The Honorable John H. Chafee

Chairman

Committee on Environment

and Public Works

United States Senate

Washington, D.C. 20510

The Honorable Max Baucus

Ranking Minority Member

Committee on Environment

and Public Works

United States Senate

Washington, D.C. 20510

The Honorable Pete V. Domenici

Chairman

Subcommittee on Energy and Water Development

Committee on Appropriations

United States Senate

Washington, D.C. 20510

The Honorable Harry Reid

Ranking Minority Member

Subcommittee on Energy

and Water Development

Committee on Appropriations

United States Senate

Washington, D.C. 20510
The Honorable Orrin G. Hatch

Chairman

Committee on the Judiciary

United States Senate

Washington, D.C. 20510

The Honorable Patrick J. Leahy

Ranking Minority Member

Committee on the Judiciary

Unite States Senate

Washington, D.C. 20510

The Honorable Newt Gingrich

Speaker of the

U.S. House of Representatives

Washington, D.C. 20515

The Honorable Thomas Bliley

Chairman

Committee on Commerce

U.S. House of Representatives

Washington, D.C. 20515

The Honorable John D. Dingell

Ranking Minority Member

Committee on Commerce

U.S. House of Representatives

Washington, D.C. 20515

The Honorable Don Young

Chairman

Committee on Resources

U.S. House of Representatives

Washington, D.C. 20515

The Honorable George Miller

Ranking Minority Member

Committee on Resources

U.S. House of Representatives

Washington, D.C. 20515

The Honorable Dan Schaefer

Chairman

Subcommittee on Energy and Power

Committee on Commerce

U.S. House of Representatives

Washington, D.C. 20515 
The Honorable Ralph M. Hall

Ranking Minority Member

Subcommittee on Energy and Power

Committee on Commerce

U.S. House of Representatives

Washington, D.C. 20515

The Honorable Joseph M. McDade

Chairman

Subcommittee on Energy

and Water Development

Committee on Appropriations

U.S. House of Representatives

Washington, D.C. 20515

The Honorable Vic Fazio

Ranking Minórity Member

Subcommittee on Energy

and Water Development

Committee on Appropriations

U.S. House of Representatives

Washington, D.C. 20515

The Honorable Henry J. Hyde

Chairman

Committee on the Judiciary

U.S. House of Representatives

Washington, D.C. 20515

The Honorable John Conyers, Jr.

Ranking Minority Member

Committee on the Judiciary

U.S. House of Representatives

Washington, D.C. 20515 


\begin{abstract}
This report is prepared in response to the Low-Level Radioactive Waste Policy Act (the Act), Public Law 96-573, 1980, as amended by the Low-Level Radioactive Waste Policy Amendments Act of 1985, Public Law 99-240. The report summarizes the activities during calendar year 1996 related to the establishment of new disposal facilities for commercially-generated low-level radioactive waste. The report emphasizes significant issues and events that have affected progress in developing new disposal facilities, and also includes an introduction that provides background information and perspective on United States policy for low-level radioactive waste disposal.
\end{abstract}




\section{EXECUTIVE SUMMARY}

The Low-Level Radioactive Waste Policy Act, 1980 (Public Law 96-573) established as Federal policy, that the states are responsible for providing for disposal of commercially-generated low-level radioactive waste. The law encouraged states to enter into regional compacts to fulfill that responsibility and offered states who are members of compacts approved by Congress the authority to restrict use of their regional disposal facilities to waste generated within the respective regions. (The current configuration of compacts is shown in Figure 1). The 1980 legislation was enacted at the request of states, with strong support from the National Governors' Association, following the temporary closure of two of the three remaining operating disposal facilities for low-level radioactive waste in the United States.

The Low-Level Radioactive Waste Policy Amendments Act of 1985 (Public Law 99-240) (Act), reinforced the states' responsibility to provide for disposal of the waste generated within their borders, better defined the waste for which states and the Federal government are responsible, and amended the earlier law by adding a series of site development milestones along with penalties and incentives for states to develop the new disposal sites in a timely manner. The only change in the legislative scheme since the law was enacted is the result of a decision of the U.S. Supreme Court that determined that the final 1996 milestone requiring states to take title to waste if they had not provided for disposal by that time was unconstitutional. The Court held that "The purpose of the Act is not defeated by the invalidation of the take title provision, so we may leave the remainder of the Act in force." New York v. U.S. 505 U.S. 144, 172-173 (1992).

Section 7(b) of the Act requires the Department of Energy to "prepare and submit to Congress on an annual basis a report which summarizes the progress of low-level waste disposal siting and licensing activities within each compact region," and reviews other topics related to the management and disposal of low-level radioactive waste. This is the eleventh annual report prepared in response to the Act.

In 1996, compact host states actively pursued the development of new disposal facilities for a variety of reasons: to carry the investment already made to a successful conclusion; to execute established policy; to maintain public institutions involvement in the safe, long-term isolation of radioactive waste; and to comply with a requirement of current law. State sponsored programs to develop new facilities also continued because there is 
a belief that any private sector option will be unable to provide stable access to disposal capacity within a reasonable period of time-- the same motivation that led to Congress' original efforts in 1980 to make state governments, in response to their requests, responsible to provide for disposal of the waste.

While compact regions continue their efforts to establish new disposal sites, private sector initiatives outside the traditional compact structure suggest a trend toward a more hybrid system where the private sector will meet certain market demands for waste management services and co-exist with the state/compact processes. The 1995 reopening of the Barnwell, South Carolina, disposal facility to waste generators nationally, and the announcement by a private sector disposal facility in western Utah that it would increase its acceptance of some types of Class A lowlevel radioactive waste are factors that have shaped the current disposal facility configuration. The continued availability of existing disposal facilities has caused some state representatives and siting opponents to raise questions on whether there is a need for new facilities.

While host states for compact regions (and the proposed compact comprised of Texas, Maine, and Vermont) continued their efforts in 1996 to establish new disposal facilities, the unaffiliated states were engaged in more limited siting activities. New Hampshire, Rhode Island, the District of Columbia and Puerto Rico do not have programs in place to establish disposal facilities. The most active facility siting efforts in 1996 were in Texas, host state for the proposed Texas compact; North Carolina, host state for the Southeast Compact; and Ohio, host state for the Midwest Compact.

On March 29, 1996, the Executive Director of the Texas Natural Resources Conservation Commission recommended to the Commission issuance of an operating license for a disposal facility in Hudspeth County in west Texas. The draft proposed license was accompanied by an environmental and safety analysis of the proposed facility. Under Texas' licensing process, administrative hearings will be conducted on the environmental and safety analysis and the license application. If the hearings result in the issuance of a license, and if there is no subsequent litigation, construction of the disposal facility could begin in late 1998.

Following an impasse that began the previous year, the Southeast Compact Commission on October 3, 1996, authorized the transfer of funds to North Carolina, based on certain conditions, to begin additional studies intended to resolve technical issues related to the proposed disposal site in Wake County, North Carolina. The additional work, including costs of reviewing a revised license application, is expected to take 44 months. During 1996, several letters were exchanged between the Compact Commission and the Governor of North Carolina 
regarding responsibility for funding the additional site studies. At year's end, the Commission was exploring options for additional funding with the state and with waste generators in the Southeast region.

The newly formed Ohio Low-Level Radioactive Waste Facility Development Authority took steps in 1996, to launch the process for siting a disposal facility for the Midwest Compact region. On August 1, the Authority issued a request for proposals for contractors to assist the Authority in conducting a statewide screening. Following review of the bids, the Authority announced on December 9, 1996, that it would enter into negotiations with a team consisting of URS Greiner Consultants, Bechtel National, Inc., and US Ecology, Inc. The Authority estimates that three potential sites will be selected by September 1998.

Considerable national attention during 1996, as in previous years, was focused on progress in California. In 1993, the state became the first since 1970 to issue an operating license for a new low-level radioactive waste disposal facility. The proposed site is located in Ward Valley in the Mojave Desert. Because the site is located on public land administered by the U.S. Bureau of Land Management (BLM), the land must first be transferred to the state before the site can be developed. Construction of a disposal facility on the site has been delayed pending the land transfer. The BLM has stated that, before it can transfer the land, it must prepare a second supplemental environmental impact statement (EIS) to address new information that has become available since the original EIS was issued in 1991. (The first supplemental EIS was issued in 1993). In December 1996, the Interior Department issued a request for proposals from private companies to conduct the studies in support of the supplemental EIS.

Proponents of the California land transfer have taken issue with BLM's assessment, arguing that the information is neither new nor significant enough to trigger the need for a supplemental EIS. During 1996, unsuccessful efforts were made through Congress to legislatively transfer the land. By year's end, the Governor of California, several U.S. Senators and Representatives, and a number of industry organizations had endorsed a legislative proposal to transfer the land following a review of technical issues by the Nuclear Regulatory Commission. A bill incorporating the proposal is expected to be introduced into Congress during the 1997 session. In the meantime, BLM is proceeding with plans to do additional testing at the site and complete the supplemental EIS.

In addition to these developments, Nebraska entered its sixth year of review of an application to construct and operate a regional disposal facility in Boyd County. Illinois issued its final siting criteria, setting the stage for commencement of its site screening process. Connecticut, New Jersey, and Pennsylvania continued implementing programs to solicit volunteer communities through collaborative methods involving incentives and shared decision making. 
Although facility siting efforts have reached the licensing stage in several locations, costly delays are being experienced even in states that have adopted strict schedules and offered extensive opportunities for public involvement. In a report issued in May 1996, the Nuclear Energy Institute estimated that "approximately $\$ 512$ million in public and private funds has been expended on disposal facility development efforts since passage of the Policy Act in 1980." A few of the state programs have been suspended or redirected in the midst of controversy following the selection of candidate site locations. None of the state programs has proceeded according to originally estimated schedules. Many state officials and organizations that generate the waste are reluctant to depend on the development of new disposal facilities in the private sector for future disposal needs, or rely upon facilities in other states over which they have little operational control.

The year 1996 yielded few indications of the future of low-level radioactive management in the U.S. The year's activities, however, set the stage for a series of critical events that should better clarify whether the blueprint defined by regional compacts will continue to serve as the framework for national policy on low-level radioactive waste. Each of the following actions or issues that will be addressed within the next two years has the potential to significantly influence activities and decisions across the Nation:

- A decision on the transfer of land to California for the Ward Valley site;

- Congressional approval of the proposed Texas Compact, currently pending in Congress;

- The outcome of the Texas adjudicatory hearings on the draft license and the environmental and safety analysis;

- The Nebraska decision on an operating license for the proposed facility in Boyd County;

- Results from the new studies of the proposed North Carolina site; and

- The potential of currently operating disposal facilities to provide stable, long-term access to disposal. 


\section{Annual Report to Congress on Low-Level Radioactive Waste Management Progress}

Contents

ABSTRACT $\ldots \ldots \ldots \ldots \ldots \ldots \ldots \ldots \ldots \ldots \ldots \ldots \ldots \ldots \ldots \ldots \ldots \ldots \ldots \ldots$

EXECUTIVE SUMMARY $\ldots \ldots \ldots \ldots \ldots \ldots \ldots \ldots \ldots \ldots \ldots \ldots \ldots$ iv

INTRODUCTION $\ldots \ldots \ldots \ldots \ldots \ldots \ldots \ldots \ldots \ldots \ldots \ldots \ldots \ldots \ldots \ldots \ldots \ldots \ldots \ldots \ldots$

LOW-LEVEL RADIOACTIVE WASTE POLICY THROUGH $1996 \ldots \ldots \ldots \ldots \ldots \ldots \ldots$

DIFFERING APPROACHES IN $1996 \ldots \ldots \ldots \ldots \ldots \ldots \ldots \ldots \ldots \ldots$

Unaffiliated states re-examine approach siting efforts

(Massachusetts, Michigan, New York)

Compact host states continue commitment to develop disposal sites

(Texas, North Carolina, Ohio)

STATUS OF WARD VALLEY, CALIFORNIA, SITE $\ldots \ldots \ldots \ldots \ldots \ldots \ldots \ldots$

KEY EVENTS IN OTHER STATES AND REGIONS .

Connecticut, Illinois, Nebraska, New Jersey,

Pennsylvania, South Carolina, Washington

OTHER ANNUAL REPORT TOPICS 


\section{Annual Report to Congress on Low-Level Radioactive Waste Management Progress}

\section{INTRODUCTION}

Section 7(b) of the Low-Level Radioactive Waste Policy Act (Public Law 99-240) (Act), requires the Department of Energy to:

“...prepare and submit to the Congress on an annual basis a report which (1) summarizes the progress of low-level waste disposal siting and licensing activities within each compact region, (2) reviews the available volume reduction technologies, their applications, effectiveness, and costs on a per unit volume basis, (3) reviews interim storage facility requirements, costs, and usage, (4) summarizes transportation requirements for such wastes on an inter- and intra-regional basis, (5) summarizes the data on the total amount of low-level waste shipped for disposal on a yearly basis, the proportion of such wastes subjected to volume reduction, the average volume reduction attained, and the proportion of wastes stored on an interim basis, and (6) projects the interim storage and final disposal volume requirements anticipated for the following year, on a regional basis."

This is the eleventh annual report prepared in response to the Act. As with previous reports in this series, the focus of the report is on progress in establishing new disposal facilities for low-level radioactive waste, and on contemporary issues that may affect progress. The final section of this report addresses the other topics specified in the Act. 


\title{
LOW-LEVEL RADIOACTIVE WASTE POLICY THROUGH 1996
}

United States policy on the disposal of commercially-generated low-level radioactive waste has evolved through several distinct periods. In the 1950's, the Atomic Energy Commission (AEC), predecessor agency to the Department of Energy, disposed of all radioactive wastes generated by the few organizations outside the agency that were licensed to possess nuclear materials.

During the late 1950 's, the AEC licensed several firms to provide ocean disposal of certain low-level radioactive wastes. In 1960, at the urging of companies in the private sector, the AEC announced that it would license land disposal facilities and would phase out the use of AEC facilities for disposal of commerciallygenerated low-level radioactive waste. The AEC expected the facilities to be developed in various regions in response to market demand. Under the new policy, such facilities were required to be located on governmentowned land, either state or Federal.

About the same time, states began to assume authority for licensing and regulating the possession of certain radioactive materials, including low-level radioactive waste, as part of the "agreement state" program under a 1959 amendment to the Atomic Energy Act of 1954 (Section 274). These actions launched the era of private sector responsibility for the disposal of low-level radioactive waste. In the 1960's and 1970's, six commercially-operated disposal facilities were licensed to operate. Following are the original low-level radioactive waste disposal facilities and their operating dates:

\author{
Beatty, Nevada (1962-1992) \\ West Valley, New York (1963-1975) \\ Maxey Flats, Kentucky $\quad(1963-1977)$ \\ Richland, Washington (1965--) \\ Sheffield, Illinois (1968-1978) \\ Barnwell, South Carolina (1971--)
}

Although all sites operated within the regulatory guidelines at that time and neither public health or safety were compromised, remedial actions have been necessary to address the migration problems. The West Valley, Maxey Flats and Sheffield, Illinois, sites closed in the 1970's, (Maxey Flats is a superfund site). Each site used a relatively simple approach called "shallow land burial," in which waste is placed into excavated trenches. By 
comparison, the trend in today's practices has been toward more highly engineered facilities to take advantage of technological advances currently available and satisfy past facility performance based concerns.

In 1982, the Nuclear Regulatory Commission developed comprehensive regulations designed to address disposal facility siting, operations, closure, waste form, and institutional control related to long-term financial assurance and public confidence. No new disposal sites to replace those that had closed were being developed at that time. Public concerns with radioactive waste disposal issues continued to increase during this time period, which did not make new facilities attractive for development.

Concerned that the remaining three disposal sites might be required indefinitely to meet the national demand for disposal capacity, political leaders in Nevada, South Carolina, and the State of Washington began to exert pressure for more state control of low-level radioactive waste disposal. They were also concerned about a possible increase in waste volumes as new nuclear power reactors came on line during the decade. They urged leaders in other states to become more active in the development of new disposal sites and asked the Nuclear Regulatory Commission to help through its licensing and regulatory role.

When these efforts had little effect, the governors of Nevada, South Carolina, and Washington, individually and collectively through organizations such as the National Governors' Association, proposed Federal legislation that would allow states to enter into compact regions for disposal of low-level radioactive waste. The Low-Level Radioactive Waste Policy Act, enacted late in 1980, was a Congressional policy statement that encouraged states to form compacts. These compacts, however, could not exclude out-of-region waste prior to 1986 , and thereafter could exclude such waste only if they had been approved by Congress in subsequent Federal legislation. The Act, as originally enacted, declared it Federal policy that states are responsible for the disposal of low-level radioactive waste. (The current configuration of regional compacts is shown in Figure 1).

Although seven compacts were submitted to Congress for approval between 1983 and 1985, Congress did not immediately approve them. Given the time that had elapsed, it appeared unlikely new disposal sites could be established by 1986, after which access to the three remaining operating facilities could be denied. This would leave many generators without access to disposal capacity and raised concerns about temporary storage. Congress responded to the potential lack of disposal by including in the Low-Level Radioactive Waste Policy Amendments Act of 1985 (Public Law 99-240) interim access to the three operating facilities through 1992, but also added the site development milestones as incentives to develop new facilities. Supporters of the legislation believed the 
milestones would lead to the establishment of new disposal sites by 1993, or at least by 1996 . The 1985 amendments also added Section 5(d)(2) to require that any state unable to provide for disposal after 1995 "take title" to the waste or assume liability for all damages incurred by a generator as a consequence of the failure of the state to take title. In 1992, however, the U.S. Supreme Court determined that the "take title" provision of the Act was unconstitutional (but severable from the rest of the Act) in a lawsuit brought by New York State and others challenging the constitutionality of the Act. The Court's decision determined that "The purpose of the Act is not defeated by the invalidation of the take title provision, so we may leave the remainder of the Act in force." New York v. U.S., 505 U.S. 144, 172-173 (1992). Although there was some initial expectation that the Court's decision would have an adverse impact to disposal facility siting efforts, such efforts continued.

In 1992, the site at Beatty, Nevada, closed leaving two operating sites, one in Washington State and one in South Carolina. The Barnwell, South Carolina, site was closed to out-of-state waste from July 1994 to June 1995. In 1995, South Carolina enacted legislation withdrawing from the Southeast Compact and repealing a law that would have closed the disposal facility in that state beginning January 1,1996 . In promoting the state's withdrawal from the Compact, the Governor expressed impatience with North Carolina's lack of progress in developing a new regional disposal facility.

Since the original enactment of the Act in 1980, states have made substantial efforts to establish new disposal sites. From 1982 through 1987, nine compact regions were formed, host states chosen, enabling legislation enacted by states, and site development programs begun. Given the opposition to siting activities in most jurisdictions, no new disposal facilities have been constructed. In some states, site development programs are undergoing redirection and certain activities have been suspended (Massachusetts, Michigan, New York). In some, site selection processes were halted, and then resumed or started over using new criteria or procedures (Connecticut, Illinois, Pennsylvania, Texas). And in other states, while the programs have maintained continuity, the pace of site development has been much slower than originally estimated schedules, (Nebraska, New Jersey, North Carolina). One license has been issued to construct and operate a new disposal facility (California); a favorable license decision has been announced in one state (Texas), subject to adjudicatory hearings on the decision; and a license application is under review in two other states (Nebraska and North Carolina).

Compact host states continue with the momentum of prior years to actively pursue the development of new disposal facilities for a variety of reasons: to carry the investment that has already been made to a successful conclusion; for reasons of policy -- they believe that the safe, long-term isolation of radioactive waste is a public 
issue best addressed by public institutions; and a matter of existing law. State-sponsored programs to develop the new facilities continue to be supported even though there are private sector interests in providing a portion of the disposal capacity for low-level waste.

While most states continue their efforts, several factors appear to have softened the approach taken by some states to build new facilities. These include substantial reductions over the past decade in the volume of waste requiring disposal, and more recent interests of the private sector in meeting a portion of the demand for disposal outside of state-sponsored programs. Initiatives by the private sector suggest the likelihood that a more hybrid system in which private efforts to meet market demands for waste management services will co-exist, however uneasily, with the public sector processes of the states and compacts. The reopening of the Barnwell, South Carolina, disposal facility to waste generators nationally, and the announcement by a disposal facility in Clive, Utah, that it would increase its acceptance of some types of Class A low-level radioactive waste are factors that have relieved some of the pressure to complete the siting of new disposal facilities.

Some waste generators are concerned that the South Carolina facility may not remain open for their longterm waste management plans. The 12-month break in service between July 1994 and June 1995 suggests that the State could limit access to the Barnwell facility in the future. Disposal capacity needed for the anticipated effects of decommissioning of nuclear powerplants has also been raised as a concern. The Barnwell site capability, however, includes capacity for decommissioning waste.

Concerns over the continued availability of the Barnwell site, along with current limitations on the kinds of waste accepted at the Clive, Utah, facility, suggest that additional options are still needed. Some utilities may see long-term storage of waste, and the possibility of its ultimate entombment in the reactor building, as an alternative that is preferable to the uncertain outcomes associated with other options. At least one utility is exploring an onsite, hold-for-decay storage option for much of its shorter lived wastes. The economics of onsite disposal options may not be fully analyzed, but when compared to high offsite disposal costs, onsite options begin to look attractive. Decommissioning studies done to date generally show offsite disposal available today is a preferred option when compared to uncertain future options. While the entombment approach can be considered in NRC's ongoing effort to revisit its decommissioning regulations, there are no current regulations in place to implement this approach. 
State sponsored efforts to develop low-level radioactive waste disposal facilities have had a mixed record of success. Programs that began optimistically, with strict schedules and extensive opportunities for public involvement, have been plagued by costly delays. In a report issued in May 1996, the Nuclear Energy Institute estimated that "approximately $\$ 512$ million in public and private funds has been expended on disposal facility development efforts since passage of the Policy Act in 1980." Several states have suspended or redirected their programs in the midst of controversy following the selection of candidate site locations. None of the programs has proceeded in accordance with its original development schedule.

The year 1996 yielded few indications of the future of low-level radioactive management in the U.S. The year's activities did, however, set the stage for a series of critical events that should better clarify whether the blueprint defined by regional compacts will continue to serve as the framework for a national policy. Each of the following actions or issues that will be addressed within the next two years has the potential to significantly influence activities and decisions across the Nation:

- A decision on the transfer of land to California for the Ward Valley site;

- Congressional approval of the proposed Texas/Maine/Vermont Compact, currently pending in Congress;

- The outcome of the Texas adjudicatory hearings on the draft license and the environmental and safety analysis;

- The Nebraska decision on an operating license for the proposed facility in Boyd County;

- Results from the new studies of the proposed North Carolina site; and

- The potential of currently operating disposal facilities to provide stable, long-term access to disposal. 


\section{DIFFERING APPROACHES IN 1996}

During 1996, states unaffiliated with compacts appeared to be taking a wait-and-see approach or pausing to examine their options, while compact host states continued to pursue solutions with varying degrees of success.

\section{Unaffiliated states re-examine approach to siting efforts}

During 1996, Massachusetts joined Michigan and New York as major industrial states that have redirected and decelerated their programs for development of new disposal sites. Massachusetts has suspended certain siting efforts to shift emphasis toward a volunteer approach. Two other unaffiliated states, New Hampshire and Rhode Island, as well as the District of Columbia and Puerto Rico, who have the same responsibilities as states, have never adopted programs to establish disposal facilities.

Massachusetts. As part of a reorganization of state government, the Governor, in January 1996, proposed eliminating 262 state agencies, including the Massachusetts Low-Level Radioactive Waste Management Board. The legislature did not agree to eliminate the agency.

In January 1996, the Board issued for public review and comment a report entitled, "Draft Statewide Mapping and Screening Protocol and Procedures." In February, the Board conducted three workshops and a briefing session on the information described in the report. On March 27, 1996, the Board voted to suspend "certain site selection activities, but to complete others as it continues to monitor the changes in the national situation regarding LLRW management." The activities that were suspended were those associated with identifying areas, locations, and potential sites for the disposal facility. The remaining activities are focused primarily on planning.

Michigan. In 1996, a bill was introduced in the Michigan legislature that would have reauthorized a process for development of a low-level radioactive waste facility in the state, but the legislature took no action on the bill. The bill was prepared in response to legislation enacted in 1994, which initiated planning to create a new siting process. Under the 1994 law, a panel was appointed to advise the Michigan Low-Level Radioactive Waste Authority on approaches to siting a low-level radioactive waste management facility in the state. The 
Board of Governors met several times in 1995 and drafted a plan to site a waste management facility through a volunteer process. The final report on the plan was submitted to the legislature in October 1995.

Previously, Michigan had launched a site development program in the late 1980's as host state for the Midwest Compact region, but the program stalled in the face of local opposition after candidate sites were selected through a top-down screening process. In 1991, the state's membership in the compact region was revoked by the Compact Commission based on the conclusion that Michigan was not going to be able to fulfill its host state responsibilities to the compact. Michigan was relatively inactive on disposal site development until 1994.

The bill reauthorizing a site development program is expected to be reintroduced into the legislature during the 1997 session. Those who support reauthorization of the siting program have expressed concern that waste generators may be reluctant to provide funding for the project, as long as they have access to disposal facilities in South Carolina and Utah.

New York. During 1996, the State of New York continued to monitor low-level radioactive waste generation and management activities within the state, and national developments related to the availability of disposal capacity.

In 1989, the New York Low-Level Radioactive Waste Siting Commission identified five candidate sites for a disposal facility through a top-down screening process. (Under top-down screening, site locations are selected through a map overlay process whereby land area is eliminated from consideration in successive steps until only the candidate sites remain.) Following strong local protest over the selection of candidate disposal site locations, the Governor, in 1990, suspended site evaluation activities. That year, the state's low-level radioactive waste law was revised to require selection and approval of a disposal method before re-initiation of site selection activities.

In 1995, funding for the Siting Commission was phased out and its activities ceased. Although New York officials generally do not consider the low-level radioactive waste issue to be resolved, the availability of the South Carolina and Utah disposal facilities has reduced the immediate need to pursue the establishment of new waste facilities within the state, and the state is reevaluating its low-level radioactive management alternatives. 


\section{Compact host states continue commitment to develop disposal sites}

Host states for compact regions during 1996 continued their efforts to site or license regional disposal facilities with differing degrees of intensity. Perhaps most notable among these efforts were the development of a draft operating license for a disposal facility in Hudspeth County, Texas, a decision by the Southeast Compact Commission to resume funding for investigations of a proposed regional disposal site in North Carolina, and launching of a new siting program in Ohio.

\section{Texas. On March 29, 1996, the Executive Director of the Texas Natural Resources Conservation} Commission recommended to the Commission issuance of an operating license for a proposed low-level radioactive waste disposal facility. The site location, known as Eagle Flat or the Faskin Ranch, is located in far west Texas, near the town of Sierra Blanca in Hudspeth County. The site location was selected from a study area designated in law by the Texas legislature after selection of two previous candidate sites resulted in political and public opposition.

The draft proposed license was accompanied by an environmental and safety analysis of the proposed facility which concluded that "issuance of a license for the proposed project will not pose an unacceptable risk to public health and safety or cause a long-term detrimental impact on the environment." Under Texas' licensing process, an administrative hearing will be conducted on the environmental and safety analysis and the license application. Activities preliminary to the hearings, including discovery and depositions, began in August 1996, and the formal hearings are scheduled to begin January 1998. The hearings will be under the auspices of an administrative law judge with the Texas State Office of Administrative Hearings. If the hearings result in the issuance of a license, and if there is no subsequent litigation, construction of the disposal facility could begin in late 1998.

During 1996, Texas, along with Maine and Vermont, continued to push for Congressional approval of a low-level radioactive waste disposal compact among the three states. Texas approved the compact legislation in 1993. Maine and Vermont approved it in 1993 and 1994, respectively. Texas officials expected the compact to be approved by Congress in 1995, but failed to secure the two-thirds votes necessary for passage on the consent calendar. The compact was reintroduced in 1996, but did not come up for a vote. It is expected to be reintroduced in Congress in 1997. 
North Carolina. Renewed efforts to evaluate the Southeast Compact's proposed regional site in Wake County, North Carolina, have been delayed over two related matters: technical questions about the site, and funding for additional work to resolve the technical questions to complete the project through facility licensing.

During review of the license application for the proposed facility, the North Carolina Division of Radiation Protection raised a number of questions about the long-term ability of the site to protect public health and safety. On May 31, 1996, the North Carolina Low-Level Radioactive Waste Management Authority and its contractors, Harding Lawson Associates and Chem-Nuclear Systems, Inc., issued a "Licensing Work Plan," which describes a process to address and resolve issues raised by the Division. The Plan, which was developed in close consultation with the Division, is intended to represent a consensus between the two agencies. It sets forth a schedule and activities that will lead to a decision by the Division on an operating license for the proposed facility.

The Authority estimates that it will take 44 months and cost $\$ 27$ million to implement the Plan. As of mid-year, the Southeast Compact Commission reported a balance of approximately $\$ 22$ million in uncommitted funds, leaving a deficit of approximately $\$ 5$ million that would be needed to implement all the work described in the Plan. This does not include substantial costs associated with actual construction of the disposal facility following an affirmative licensing decision.

During 1996, several letters were exchanged between the Compact Commission and the Governor of North Carolina regarding responsibility for funding the work. The Commission noted that the terms of the Southeast Compact provide that the Commission is not responsible for costs associated with "the creation of any facility." Although not mandated to provide funding, the Compact Commission has provided approximately 70 percent of the funding for site development through 1996. Funding from the Compact Commission has come from fees assessed on waste disposed at the Barnwell, South Carolina, disposal facility, prior to South Carolina's withdrawal from the Southeast Compact. The Governor of South Carolina noted that North Carolina state law provides that costs associated with the project should be borne by the waste generators who would be served by the regional disposal facility, a funding principle generally applied in most of the compact regions. To date, North Carolina has expended approximately $\$ 30$ million of state funds on the project and continues to fund the project operating expenses of the Authority and the regulatory agencies.

At a special meeting on October 3, 1996, the Commission passed a motion to release funds to the Authority on a quarterly basis to cover the Authority's expenses in conducting the early stages of the work 
described in the Plan. The release of funds is conditioned upon several provisions requiring demonstrations of commitment to the project on the part of North Carolina. The resolution also calls upon the Commission's officers and staff to work with the Authority, waste generators, and other parties to "develop realistic models of cost and schedules for placing a site into operation and to develop realistic strategic approaches and agreements for the necessary funding." The Authority is expected to begin the work described in the Plan by January 1997.

Ohio. In June 1995, Ohio enacted legislation authorizing a program to develop a low-level radioactive waste disposal facility for the Midwest Compact region. Following a model established by the majority of other states developing new disposal sites, the Ohio legislation established a new state agency, the Ohio Low-Level Radioactive Waste Facility Development Authority, to site, develop and operate the disposal facility. The law requires that a contractor selected by the Authority conduct a statewide screening process to identify candidate sites for the facility. (Under such processes, candidate sites are generally selected through phased map overlay processes using the best available data, subsequently eliminating more land based on the progressive application of mapping criteria until only suitable candidate areas remain. The candidate areas are then subject to extensive onsite investigations to determine specific site suitability.)

In 1996, the newly formed Authority took steps to launch the siting process. On August 1, the Authority issued a request for proposals for contractors to assist the Authority in conducting a statewide screening. Seven proposals were received, with four of the bidders selected to give oral presentations on their proposals at a public meeting in November. On December 9, 1996, the Authority announced that it would enter into negotiations with a team consisting of URS Greiner Consultants, Bechtel National, Inc., and US Ecology, Inc. The Authority estimates that three potential sites will be selected by September 1998.

On May 9, 1996, Missouri became the final Midwest Compact state to enact amendments to the terms of the original Compact. The amendments establish regional remedial action and long-term care funds, provide for disposal capacity limits, address financial and liability issues, clarify the definition of low-level radioactive waste, and set forth a framework for judicial review. The amendments also establish milestones and penalties to ensure timely development of future disposal facilities. The amendments are expected to be introduced for Congressional approval during the 1997 Congressional session. 


\section{STATUS OF WARD VALLEY, CALIFORNIA, SITE}

In 1993, California as host state for the Southwestern Compact (Arizona, California, North Dakota, South Dakota) became the first state since 1970 to issue an operating license for a new low-level radioactive waste disposal facility. Last year's Annual Report to Congress on Low-Level Radioactive Waste Management Progress described California's efforts to obtain the land on which the proposed disposal facility is located from the Bureau of Land Management (BLM) under the Department of the Interior.

A number of issues related to the land transfer continued to be addressed in 1996. On January 18, the California Supreme Court refused to entertain an appeal from a California appellate court's decision rejecting a claim that the site license should be voided and adjudicatory hearings held because of information that became available after the license was issued. On February 15, the Deputy Secretary of the Interior announced his intent to seek "two additional studies at the proposed Low-Level Radioactive Waste (LLRW) site in Ward Valley that will address public concerns that have been raised since the Environmental Impact Statement was completed and follow through on recommendations made by a National Academy of Sciences panel in May, 1995." The studies involve estimating the travel time of tritium in a desert environment. By the end of 1996, the Department of the Interior and the Department of Energy's Lawrence Livermore National Laboratory had discussed procedures and methodologies for the proposed studies based on a request to the Department of Energy from the Deputy Secretary of the Interior for technical assistance.

The BLM also maintains that, before it can transfer the land, it must prepare a second supplemental environmental impact statement (EIS). The purpose of the supplemental EIS would be to address what the Interior Department perceives is new information that has become available since the original EIS was issued in 1991, and since the first supplemental EIS was issued in 1993. Proponents of the land transfer have taken issue with BLM's assessment, arguing that the information is neither new nor significant enough to trigger the need for another supplemental EIS. On December 11, 1996, the BLM issued a request for proposals (RFP) inviting contractors to submit bids to conduct the work. The schedule in the RFP indicates that the work should be completed within 335 days following a formal notice to the selected contractor to proceed.

Meanwhile, proponents of the site have been pursuing a legislative transfer of the land through Congress. The first legislative effort to transfer the land was in the Balanced Budget Act of 1995, H.R. 2491, which was vetoed by the President in December 1995. On March 7, 1996, the Ward Valley Land Transfer Act, S. 1596, was 
introduced into the Senate. The bill would have transferred the land to the state of California upon fulfillment of certain conditions: execution of a written commitment to carry out environmental monitoring, and protection measures recommended in 1995 by the National Academy of Sciences. The bill was reported to the Senate by the Committee on Energy and Natural Resources on March 7, but no action was taken on the bill during the 1996 session.

In September 1996, California biotechnology industry leaders proposed an approach intended to assist the BLM in resolving its concerns over the Ward Valley site. The proposal called for Federal legislation directing the $\mathrm{NRC}$ to conduct an expedited review of technical issues identified by the Interior Department. Under the proposal, the NRC would conclude its review by March 1, 1997. If the NRC found that the conditions of the site license issued by California in 1993 adequately protect public health and safety, then the land would be transferred to the state under Federal legislation. If the NRC found deficiencies, the land would be transferred subject to correction of the problems. By year's end, the Governor of California, several Senators and Representatives, and a number of industry organizations had endorsed the compromise proposal, but Congress had not acted on it.

In the absence of a regional disposal facility, many waste generators in the Southwestern Compact region have begun shipping waste to the operating disposal facilities in South Carolina and Utah, while others have chosen to store their waste on site. Statements issued by a biomedical group indicate that some generators believe that depositing waste in the South Carolina facility might subject them to long-term liabilities that they had not previously faced. Prior to 1993, most waste generators in the states comprising the Southwestern region shipped their low-level radioactive waste to the disposal facilities in Nevada and Washington State, and only a few have shipped waste across the country to the South Carolina facility. 


\section{KEY EVENTS IN OTHER STATES AND REGIONS}

Other states have been involved in planning for the establishment of new disposal facilities, or operating existing facilities. Key activities in Connecticut, Illinois, Nebraska, New Jersey, Pennsylvania, South Carolina, and Washington are summarized below. Maine and Vermont have enacted state legislation to join the State of Texas in a new compact (see page 9).

\section{Connecticut pursues volunteer process}

New Jersey and Connecticut constitute the Northeast Compact. In 1987, the Compact Commission decided that both states should establish disposal facilities.

The Connecticut Hazardous Waste Management Service (CHWMS) executed a top-down screening process (see page 8) leading to selection of three candidate sites in June 1991. Following strenuous local objections, the state enacted legislation in May 1992 eliminating the three chosen sites and directing CHWMS to develop new siting criteria. The law did not specify a site selection method. Since then, CHWMS has prepared a new plan that features a voluntary approach to site selection. This plan was submitted to the Connecticut legislature in February 1993. Since the legislature did not exercise its option to disapprove the plan within 60 days, the plan has gone into effect.

In 1996, CHWMS decided to slow its voluntary siting process to investigate an alternative approach to disposal referred to as "assured storage." The concept was first described by authors of journal articles in 1995 and 1996, as a long-term waste isolation system that relies more on engineered barriers and institutional control than on site characterization. It was proposed primarily as an alternative for states pursuing new low-level radioactive waste disposal facilities in humid areas in the eastern U.S., where states are generally much smaller in size, and there is less land area that meets regulatory requirements for traditional disposal systems. Critics of the concept raise concerns in several areas: long-term storage looks like disposal without the rigor of a disposal license review process that would raise public credibility issues; concept may be inconsistent with current Act; and states that are farther along in their siting effort are concerned that the introduction of the "assured storage" concept to their process may adversely affect current siting efforts. The NRC has stated that although current regulations do not specifically provide for assured storage, they would entertain a petition from a state to formally address the concept for low-level waste radioactive waste management. At year's end, Connecticut was evaluating the comparative costs of an assured storage system and a traditional disposal system. CHWMS had 
also asked the State Attorney General whether establishment of an assured storage facility would be consistent with applicable provisions of state and Federal law.

\section{Illinois panel issues new site selection criteria}

Illinois and Kentucky constitute the Central Midwest Compact. Illinois is the compact region's host state for a disposal facility because it generates most of the compact's low-level radioactive waste.

Following rejection of a proposed disposal site location in Martinsville by a legislatively created panel, Illinois enacted legislation in 1993 establishing a revised process for selecting a site. The Illinois Low-Level Radioactive Waste Task Group was appointed by the Governor in late 1993 to develop site-selection criteria. Using the criteria, the State Geological Survey and the State Water Survey will conduct a top-down screening of the state (see page 8) to identify "at least 10 locations, each of at least 640 acres, that appear likely to meet the criteria." In addition to the statewide screening, the Scientific Surveys will evaluate all lands volunteered by land owners or units of local government. Under Illinois law, volunteered land must be given preference in the site selection process.

A contractor selected by the Department of Nuclear Safety will identify three sites from the suite of at least ten, and the Task Group will determine whether the three meet the site selection criteria. From three approved sites, the contractor will then select one for detailed characterization.

In August 1995, the Task Group released draft proposed site selection criteria for public comment. During 1996, following a series of informational meetings and public hearings, the Task Group released a second draft of the proposed site selection criteria for additional public comment. On December 19, 1996, the Task Group adopted the final report, "Site Selection Criteria for a Low-Level Radioactive Waste Disposal Facility." The report sets the groundwork for the screening process.

\section{Nebraska license application review enters sixth year}

Nebraska is host state for the Central States Compact. Other member states are Kansas, Oklahoma, Arkansas and Louisiana. 
In July 1990, US Ecology, site operator-designee for the Central States Compact, submitted a license application to develop and operate a regional disposal facility in Boyd County, Nebraska. The Nebraska Department of Environmental Quality (NDEQ) and the Department of Health (NDOH) determined that the application was complete in December 1991.

In 1993, NDEQ and NDOH issued an "Intent to Deny a License" action, citing the presence of wetlands on the 320-acre site, and their administrative definition of site suitability requirements. In response, US Ecology submitted an amended application that reduced the size of the site to 110 acres in order to exclude wetlands that were located within the buffer zone of the original site boundaries. The state regulatory agencies then withdrew their Intent to Deny action.

The possible presence of a wetland under one acre in size in the buffer zone of the reconfigured site remains an issue in the state's technical review and a topic of discussion between US Ecology and the U.S. Army Corps of Engineers. On August 9, 1996, the U.S. Army Corps of Engineers authorized mitigation for US Ecology to fill the wetland, in exchange for restoring a six-acre previously drained basin within the original site boundaries to wetland status. By the end of 1996, the NDEQ had not allowed the mitigation to proceed to allow for further consideration during the more detailed technical review process.

During 1996, the NDEQ and NDOH continued to prepare the Draft Safety Evaluation Report and Draft Environmental Impact Assessment for the proposed site to provide technical support for a decision on an operating license. Nebraska newspapers criticized the state over the lengthy application review process and a perceived inability to reach a licensing decision was likely based on non-technical issues. By the end of 1996, no target dates or schedule had been established by the state to complete the process.

In January 1996, the Compact Commission issued a proposed technical review schedule calling for a draft decision on the license application by July 1996 for public comment and hearings. The NDEQ rejected the proposed schedule. In August 1996, the Commission held a special meeting to receive public comments on the scheduling issues. On September 30, 1996, the Commission proposed that Nebraska issue a draft licensing decision between December 14, 1996, and January 14, 1997. Representatives of the state agencies reviewing the license application did not attend these Commission meetings. On November 27, Nebraska filed a lawsuit against the Commission, alleging that the Commissions' propossals relating to the review of the license application are invalid and unreasonable. By year's end, the court had taken no action on the lawsuit. 
In September 1996, the Nebraska Commissioner on the Central Compact Commission provided a memorandum to fellow Commissioners calling for a discussion of alternatives to continued pursuit of a regional low-level radioactive waste disposal facility in Nebraska. The memorandum asserts that the "arrangement that has been established to dispose of the low-level radioactive waste for the Central Interstate Compact does not appear to be viable," due to declining volumes of low-level waste generated since formation of the compact region. The Commissioner requested that the issues in the memorandum be discussed at the scheduled January 1997 meeting.

\section{New Jersey continues volunteer siting process}

New Jersey and Connecticut constitute the Northeast Compact. The Compact Commission decided that both states should establish disposal facilities.

Following the opposition that was generated in response to top-down screening processes for hazardous waste facilities in the state, New Jersey decided to conduct a voluntary approach to selecting candidate sites. In February 1995, after a public comment period, the New Jersey Low-Level Radioactive Waste Disposal Facility Siting Board formally adopted its site selection process.

Since adopting the voluntary plan, the Board has received preliminary inquiries from civic leaders, local officials, and/or landowners in over 20 municipalities. During 1996, six towns publicly expressed interest in considering hosting the disposal facility. After public meetings and discussion, the Siting Board discontinued the process in two of the towns because they did not appear to have an available suitable site. The process ended in the other four towns when the local governing bodies voted to end it. The most extensive consideration occurred in Fairfield Township in the southern part of the state over a three month period.

Throughout the year, New Jersey took numerous steps to publicize the volunteer process. One brochure distributed across the state proposes that communities consider offering land previously contaminated. The brochure points out that the site would still be required to meet standards for performance and monitoring.

\section{Pennsylvania announces Community Partnering Plan}

Pennsylvania is host state for the Appalachian Compact. Other member states are Delaware, Maryland 
and West Virginia.

Disposal site operator-designee Chem-Nuclear Systems, Inc., began a top-down screening process in 1991 to identify three potentially suitable sites to submit to the state's Environmental Quality Board (EQB) for approval. The first phase, completed the same year, eliminated about 23 percent of the state from further consideration. After phase two, completed in February 1993, 46 percent of the state was disqualified. After phase three, 75 percent of the state was disqualified. All 67 counties, however, still contained some eligible land.

Prior to commencing the final phases, Pennsylvania decided to discontinue the top-down screening approach (see page 8) in favor of a "community partnering plan," a volunteer solicitation program emphasizing shared decision-making and siting incentives. A draft version of the plan was distributed for public comment in November 1995. On March 1, 1996, following a public comment process, the Department issued the final community partnering plan. Under the plan, communities progress through distinct stages of "information, interest, negotiation, and approval." Communities can choose to terminate their participation in the process at any stage up through approval. The form of community approval, e.g., referendum, town meeting, board approval, is not pre-defined in the plan.

\section{South Carolina Supreme Court Upholds Disposial Legislation}

Under state law enacted June 28, 1995, the disposal facility near the town of Barnwell, in Barnwell County, South Carolina, began accepting low-level radioactive waste from all states except North Carolina, effective July 1, 1995. The law also withdrew the state's membership in the Southeast Compact. On April 22, 1996, the South Carolina Supreme Court upheld the constitutionality of the 1995 law. The lawsuit, brought by a coalition of organizations and individuals, asserted that the provisions withdrawing the state from the Southeast Compact and allowing the site to accept waste nationally, were unconstitutional "riders" on the annual appropriations bill. The South Carolina Constitution requires that bills be limited to a single subject, and disallows the attachment of nongermaine provisions. The Court ruled that because a tax is assessed under the law on those who ship waste to the facility, the law was germaine to the appropriations bill.

In 1996, Chem-Nuclear Systems, Inc., operator of the Barnwell site, introduced a new price structure for low-level radioactive waste disposal that has the potential to impact the volume of waste accepted at the site. The price structure is discussed in the following section on "Other Annual Report Topics." 


\section{Washington disposal site continues to serve western regions}

The "Richland" disposal site is the disposal facility for the Northwest Compact region. The disposal facility is located on the Department of Energy's Hanford reservation on land leased to the State of Washington. Under a contract with the Rocky Mountain Compact, the facility also accepts waste generated within that region. Because waste generators within the region are required to ship waste to the regional disposal facility, the State of Washington regulates disposal charges imposed by the company operating the disposal facility. During 1996, there was no change in the status of the facility. 


\section{OTHER ANNUAL REPORT TOPICS}

In addition to summarizing the progress of siting and licensing activities within the states, the Act requires the Department of Energy to report annually on several other specific topics.

\section{Volume reduction technologies}

Virtually all low-level radioactive waste received at the South Carolina and Washington sites today is treated or stabilized in some manner prior to disposal. In addition to improving the waste form, many waste treatment technologies result in significant reductions in the volume of waste requiring disposal. Treatment may take place at large, centralized commercial facilities, or at the place of generation using smaller scale treatment facilities or mobile units.

In October 1996, the Department of Energy's National Low-Level Waste Management Program published the report, "Commercially Available Low-Level Radioactive and Mixed Waste Treatment Technologies" (DOE/LLW-240). The report discusses the various forms of low-level radioactive waste and indicates which are amenable to commercially available treatment technologies. The technologies include sizing, compaction, filtration, decontamination, evaporation, separation, incineration, vitrification, immobilization/stabilization, metal recovery, and physical and chemical treatments.

A new price structure adopted by Chem-Nuclear Systems, Inc., the operator of the Barnwell site, may influence the decisions of waste generators on their current waste management practices concerning treatment options, and decisions on shipping waste for disposal or selecting storage. The new price structure, which became effective November 1, 1996, replaces a formula in which the volume of the waste was a dominant factor in determining the disposal cost. The new formula is based more on the weight and density of the waste, the radioactive content, and the dose rate. In some cases, this reduces the benefits of using treatment processes that result in very dense, compact waste forms. Chem-Nuclear maintains that the new formula is revenue neutral, although disposal costs for some generators may rise, and costs for others may be reduced. The company believes the new price structure will help waste generators stabilize their overall costs for managing low-level radioactive waste. 
One purpose cited by Chem-Nuclear for the new price structure is to mitigate the cycle in which more compact waste forms result in smaller volumes, which in turn lead to higher prices per volume of waste. ChemNuclear expects that the net effect of the new rate system will be to stabilize volumes, and thereby stabilize the revenues received by the State of South Carolina through its volume-based tax of $\$ 235$ per cubic foot of waste. Although South Carolina predicted it would receive approximately $\$ 140$ million in revenues from the low-level radioactive waste disposal tax for the period July 1995 through June 1996, actual collections were approximately $\$ 93$ million.

\section{Transportation requirements}

On September 28, 1995, the Department of Transportation, in cooperation with the Nuclear Regulatory Commission, published a final rule in the Federal Register ("Hazardous Materials, Transportation Regulations; Compatibility with Regulations of the International Atomic Energy Administration," 60 FR 50292) on offsite transportation of radioactive materials, which includes low-level radioactive waste. The purpose of the rule is to bring United States radioactive material transportation requirements in line with International Atomic Energy Agency standards, and to provide a more uniform degree of safety for various types of waste shipments.

Among other changes, the new rule revises the requirements for shipping "low specific activity" (LSA) material, which is radioactive material that does not exceed specific concentrations. A large portion of low-level radioactive waste meets the requirements to be shipped as LSA material. The new rule divides LSA material into three categories requiring levels of industrial packaging rated from 1 to 3 , with 3 being the most secure. Because the new rule lowers the radionuclide concentration levels subject to LSA packaging, the rule could require such packaging for a substantial volume of contaminated soils and uranium mill tailings that previously could be shipped as unpackaged bulk materials. The new regulations will also require the use of the international system of units for the measurement of radioactivity effective April $1,1997$.

\section{Interim storage requirements}

Section 5(b) of the Act, allowed the three states with operating disposal sites to limit the volume of waste accepted at those sites between 1986 and 1992, referred to as the "interim access period." Section 5(c) limited the volume of waste each nuclear power reactor could ship for disposal during that period. Because of these 
limits, Congress believed that many waste generators might be forced to store significant amounts of waste until new regional disposal facilities were established.

Although no new low-level radioactive waste disposal facilities have been built, the reopening of the South Carolina disposal facility and availability of the Utah facility for some kinds of low-level radioactive waste have alleviated the need for generators of large volumes of waste to provide onsite storage. While some waste generators, for a variety of reasons, choose to store their waste rather than ship it for disposal, the volumes are not believed to be significant. Smaller generators, particularly in the biomedical community, have surfaced concerns with storage needs since they typically have less on site space for storage. Although disposal is available in South Carolina, some California generators have chosen storage rather than ship waste across the country. The Nuclear Regulatory Commission, the Department of Energy, the Electric Power Research Institute, and the Nuclear Energy Institute do not routinely collect data on the amount of low-level radioactive waste stored on site at the place where it was generated. The Institute for Nuclear Power Operation collects survey information from nuclear power reactors, but has not compiled the information on the amount of low-level radioactive waste stored on site.

\section{Interim storage and disposal requirements for the coming year}

The Department of Energy does not collect data for projecting disposal requirements for the upcoming year. The economics of data collection would be far in excess of the benefits derived from the data. Generators of commercial low-level radioactive waste are regulated by the Nuclear Regulatory Commission and various state agencies, not the Department of Energy. Generally, the significant volume reduction that has taken place over the past decade readily allows the Nation's currently operating disposal sites to accommodate all of the Nation's waste. In 1996, the South Carolina and Washington sites together received approximately 471,000 cubic feet of waste for disposal. In 1985, the same two disposal sites received over 2,600,000 cubic feet of waste. The Utah site is also available for disposal of some types of low-level radioactive waste.

\section{Waste shipped for disposal}

The Department of Energy's Manifest Information Management System provides detailed information on low-level radioactive waste shipped for disposal. This system is accessible on the Internet home page for the National Low-Level Radioactive Waste Management Program at:http://www.inel.gov/national/national.html. The Department also provides data on the volumes and categories of low-level radioactive waste shipped for disposal on an annual basis in the report, the "State-by-State Assessment of Low-Level Radioactive Waste Shipped for Disposal." The report for 1995, document number DOE/LLW-237, was issued in September 1996. The annual data report for calendar year 1996 is scheduled to be published in September 1997. 


\section{Commercial Low-Level Waste Disposal Regions}
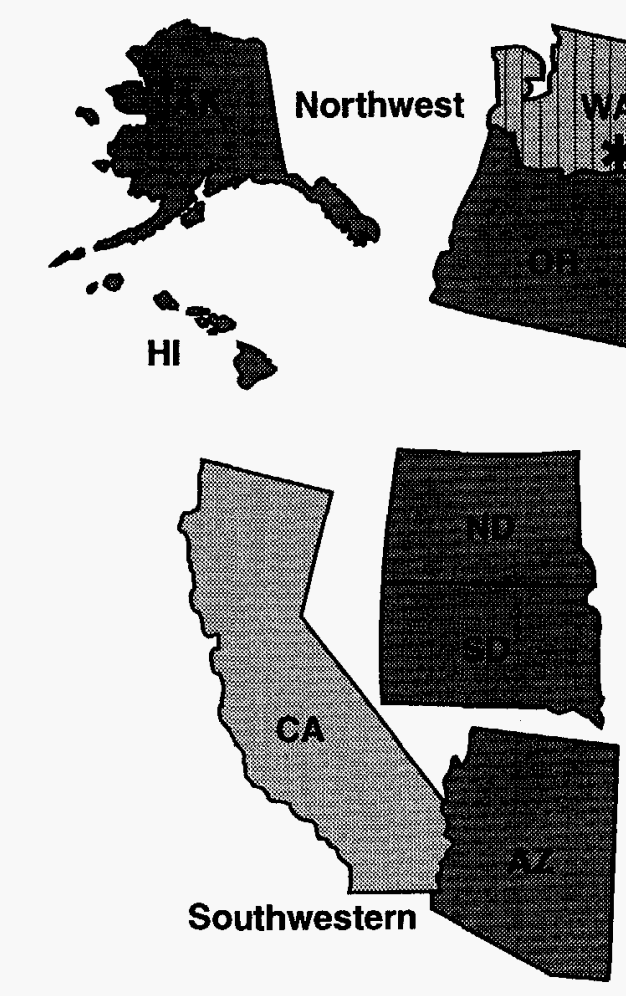

WIII Currently operating disposal site

Compact host state

Compact states

Unaffiliated state (compact proposed among TX, VT, ME)

Fig 1: Commercial Low-Level Waste Disposal Regions

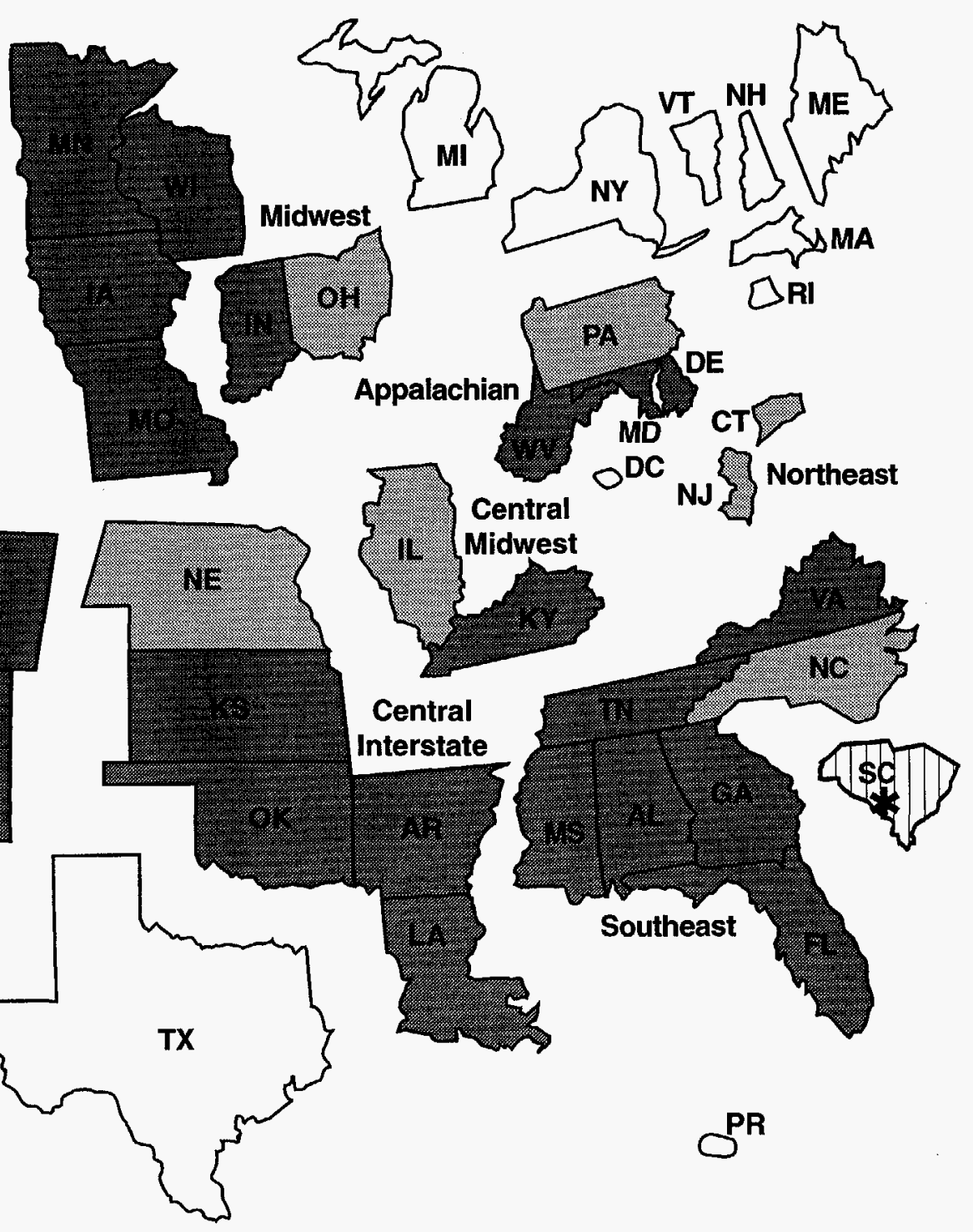

